\title{
Pengaruh Pijat Oksitosin Terhadap Produksi ASI Ibu Menyusui di Wilayah Kerja Puskesmas Sidomulyo Rawat Jalan Pekanbaru
}

\author{
Magdalena $^{1}$, Dina Auliya ${ }^{2}$, Usraleli $^{3}$, Melly $^{4}$, Idayanti $^{5}$ \\ 1,2,3,4,5 Poltekkes Kemenkes Riau, Jalan Melur No.103 Pekanbaru \\ Correspondence email: usraleli@pkr.ac.id
}

\begin{abstract}
Abstrak. Air susu ibu (ASI) merupakan makanan yang terbaik untuk bayi, karena ASI mengandung semua zat gizi yang diperlukan dalam jumlah dan perimbangan yang tepat serta mengandung zat kekebalan atau antibodi yang berfungsi melindungi bayi dari berbagai kuman penyakit. Salah satu kendala utama seorang ibu dalam pemberian ASI adalah karena produksi ASI tidak lancar. Cara yang dapat dilakukan untuk memperlancar produksi ASI adalah dengan melakukan pijat oksitosin. Tujuan penelitian ini adalah untuk mengetahui pengaruh pijat oksitosin terhadap produksi ASI ibu menyusui di Wilayah Kerja Puskesmas Sidomulyo Rawat Jalan yang dilakukan pada tanggal 21-29 Maret 2019. Sampel diambil sebanyak 16 responden, dimana responden di observasi sebelum dan sesudah intervensi menggunakan lembar observasi. Penelitian ini bersifat kuantitatif dengan desain pre experimen serta pendekatan one grup pretest postest. Data dianalisis menggunakan uji statistik Wilcoxon dan didapati nilai Z frekuensi menyusu bayi sebesar -3.573a dan $p$-value sebesar 0.000 sedangkan nilai Z frekuensi buang air kecil bayi sebesar -3.547a dan $p$-value sebesar 0.000 , yang berarti $(p<0,05)$. Hasil tersebut menunjukkan adanya pengaruh pijat oksitosin terhadap ibu menyusui. Dengan demikian, penelitian ini diharapkan dapat direkomendasikan kepada petugas kesehatan untuk memberikan pengetahuan tentang cara meningkatkan produksi ASI pada ibu menyusui melalui pijat oksitosin.
\end{abstract}

Kata kunci: ASI; Ibu Menyusui; Pijat Oksitoksin

\begin{abstract}
Breast milk (ASI) is the best food for babies, because breast milk contains all the nutrients needed in the right amount and balance and contains immunity or antibodies that function to protect babies from various germs and diseases. one of the main obstacles of a mother in breastfeeding is because the milk production is not smooth. The method that can be done to facilitate ASI production is to do oxytocin massage on breast milk production in breastfeeding mothers in the Sidomulyo Outpatient Health Center Working area conducted on March 21-19 2019. The sample was taken as many as 16 respondents where respondents were observed before and after the intervention using sheets observation. This research is quantitative with a pre-experimental design and one group pretest posttest approach. Data were analyzed using Wilcoxon statistical test and it was found that the $Z$ frequency of breastfeeding frequency was $-3,573$ a and p-value was 0,000 while the $Z$ value of frequency of infant urination was $-3,547 a$ and p-value was 0,000, which means ( $p<0,05)$ These results indicate the influence of oxytocin massage on nursing mothers. Thus, this study is expected to be recommended to health workers to provide knowledge on how to increase breast milk production in nursing mothers through oxytocin massage.
\end{abstract}

Keywords: Breastfeeding; Breast Milk; Oxytocin Massage

\section{PENDAHULUAN}

Air Susu Ibu (ASI) adalah suatu emulsi lemak dalam larutan protein laktosa dan garam-garam anorganik yang disekresikan oleh kelenjar mamae ibu, yang berguna sebagai makanan bagi bayinya. ASI eksklusif adalah pemberian ASI tanpa makanan dan minuman tambahan lain pada bayi berumur nol sampai enam bulan. Bahkan air putih tidak diberikan dalam tahap ASI eksklusif ini. ASI dalam jumlah yang cukup merupakan makanan terbaik pada bayi dan dapat memenuhi kebutuhan gizi bayi selama 6 bulan pertama. ASI merupakan makanan alamiah yang pertama dan utama bagi bayi sehingga dapat mencapai tumbuh kembang yang optimal (Walyani, 2015).

Dari sudut pandang ilmiah dapat dibuktikan bahwa ASI merupakan makanan yang terbaik dan yang paling ideal untuk bayi. Disebut makanan yang terbaik untuk bayi, karena ASI mengandung semua zat gizi yang diperlukan dalam jumlah dan perimbangan yang tepat. Di samping itu ASI mengandung zat kekebalan atau antibodi yang berfungsi melindungi bayi dari berbagai kuman penyakit (Widuri, 2013). Menurut Pusat Data dan Informasi Kementrian Kesehartan RI tahun 2014, bagi ibu yang menyusui bayi, kelancaran air susu ibu (ASI) sangat penting untuk memenuhi kebutuhan bayi. Air susu ibu merupakan makanan yang terbaik dan yang paling ideal untuk bayi, karena ASI mengandung zat kekebalan yang akan melindungi bayi dari penyakit diare dan menurunkan kemungkinan bayi terkena penyakit infeksi telinga, batuk, pilek, dan penyakit alergi.

Pentingnya menyusui yang optimal bisa menyelamatkan nyawa lebih dari 800.000 anak di bawah usia 5 tahun di setiap tahunnya. Cara yang tepat untuk mempertahankan produksi pemberian air susu ibu (ASI) adalah sering menyusui bayi. WHO dan UNICEF merekomendasikan inisiasi menyusui dini dalam waktu 1 jam dari lahir. Jika bayi diberikan susu formula, maka untuk kembali ke ASI mungkin tidak menjadi pilihan karena produksi ASI berkurang (WHO, 2016). Di Indonesia proporsi pola pemberian ASI pada bayi umur 
0-5 bulan hanya sebesar $37,3 \%$, persentase ini masih sangat rendah jika dibandingkan dengan target Indonesia yaitu $80 \%$ ibu harus menyusui bayinya secara eksklusif (Riskesdas, 2018).

Di Provinsi Riau pada tahun 2016 bayi yang mendapat ASI eksklusif sebesar 56,2\%, lebih rendah daripada tahun 2015 yaitu 68,8\%. Dari 12 Kabupaten/kota di Provinsi Riau hanya 1 Kabupaten yang telah mencapai target program yaitu di Kabupaten Rokan Hilir sebesar 81,57\%. Di Kota Pekanbaru upaya meningkatkan pertumbuhan bayi dan balita serta penurunan angka kesakitan dan kematian dilakukan dengan tindakan preventif salah satunya berupa penggunaan ASI eksklusif. Pemberian ASI eksklusif pada tahun 2015 sebanyak 13.656 bayi $(71,26 \%)$ dari keseluruhan jumlah bayi usia 0-6 bulan sebanyak 19.164 bayi. Sedangkan jumlah bayi yang diberi ASI eksklusif pada tahun 2016 sebanyak 8.445 bayi $(50,67 \%)$ dari keseluruhan jumlah bayi usia 0-6 bulan sebanyak 16.666 bayi. Ini artinya terjadi penurunan yang signifikan antara tahun 2015 dan tahun 2016, untuk itu perlu digalakkan lagi tentang pentingnya ASI eksklusif bagi bayi (Dinas Kesehatan Kota Pekanbaru, 2016).

Laktasi atau menyusui mempunyai 2 pengertian, yaitu produksi ASI (prolaktin) dan pengeluaran ASI (oksitosin). Selama kehamilan hormon prolaktin dari plasenta meningkat tetapi ASI belum keluar karena pengaruh hormon estrogen yang masih tinggi. Kadar estrogen dan progesteron akan menurun pada saat hari kedua atau ketiga pasca persalinan sehingga terjadi sekresi ASI. Apabila bayi disusui, maka gerakan menghisap yang berirama akan menghasilkan ransangan saraf yang terdapat pada glandula pituitaria posterior, sehingga keluar hormon oksitosin. Hal ini menyebabkan sel-sel miopitel di sekitar alveoli akan berkontraksi dan mendorong ASI masuk kedalam pembuluh ampula (Yanti dan Sundawati, 2011).

Proses menyusui dikenal juga dengan istilah inisiasi menyusu dini, dimana ASI baru akan keluar setelah plasenta lepas. Plasenta mengandung hormon penghambat prolaktin yang menghambat pembentukan ASI. Setelah plasenta lepas, hormon plasenta tersebut tidak diproduksi lagi, sehingga air susu pun keluar. Umumnya ASI keluar 2-3 hari setelah melahirkan. Namun sebelumnya di payudara sudah terbentuk kolostrum yang baik sekali untuk bayi, karena mengandung zat kaya gizi dan antibodi pembunuh kuman. Namun ada kalanya seorang ibu mengalami masalah dalam pemberian ASI. Kendala utama adalah karena produksi ASI tidak lancar (Soleha, 2009).

Kenyataan di lapangan menunjukkan produksi ASI yang sedikit pada hari-hari pertama setelah melahirkan menjadi kendala dalam memberikan ASI secara dini. Kurang lancarnya produksi dan pengeluaran ASI pada hari-hari pertama setelah melahirkan dapat disebabkan oleh kurangnya rangsangan hormon prolaktin dan oksitosin yang sangat berperan dalam kelancaran produksi dan pengeluaran ASI (Bobak, 2012). Beberapa cara untuk membantu memperlancar pengeluaran air susu ibu di awal menyusui, maka pada ibu dapat dilakukan perawatan payudara, breastfeeding father dan salah satunya pijat refleks oksitosin. Pijat oksitosin merupakan cara untuk merangsang payudara untuk mempercepat produksi dan pengeluaran Air Susu Ibu (ASI). Pijat oksitosin adalah tindakan yang dilakukan oleh keluarga terutama adalah suami pada ibu menyusui yang berupa back massage pada punggung ibu untuk meningkatkan hormon oksitosin (Widuri, 2013).

Hormon oksitosin juga disebut "hormon kasih sayang" karena hampir $80 \%$ hormon ini dipengaruhi oleh pikiran ibu (positif atau negatif). Pikiran positif ibu akan memperlancar pengeluaran hormon ini, demikian sebaliknya. Pijatan punggung ini sangat membantu dalam pemberian air susu ibu, karena hal tersebut sangat memberikan kenyamanan pada ibu. Kenyamanan ibu akan dapat dirasakan oleh bayi, sehingga bayipun merasa nyaman dan dapat menyusu dengan lebih baik (Widuri, 2013).

Hasil penelitian Putri (2017) tentang Pengaruh Pijat Oksitosin terhadap Produksi ASI Ibu Post Partum, pada 30 responden yang dibagi dalam 2 kelompok yakni, 15 responden yang diberikan intervensi pijat oksitosin didapatkan hasil $86,7 \%$ terjadi kecukupan produksi ASI dan $13,3 \%$ yang tidak cukup produksi ASI. Namun, pada 15 responden yang tidak diberikan intervensi didapatkan hasil 46,7\% terjadi kecukupan produksi ASI dan 53,3\% yang tidak cukup produksi ASI, sehingga dapat disimpukan bahwa ada pengaruh pijat oksitosin terhadap produksi ASI ibu post partum di Puskemas Sei Langkai tahun 2017.

Berdasarkan survey awal yang peneliti lakukan bahwa cakupan pemberian ASI Eksklusif di wilayah Kerja Puskesmas Sidomulyo Rawat Jalan Pekanbaru yaitu pada tahun 2018 terdapat 171 bayi yang lahir, jumlah bayi yang mendapat IMD yaitu 157 bayi dan yang diberikan ASI Eksklusif selama 6 bulan penuh hanya 63 bayi $(38,6 \%)$. Ini menunjukkan rendahnya cakupan pemberian ASI di wilayah kerja Puskesmas Sidomulyo Rawat Jalan Pekanbaru. Hasil wawancara yang peneliti lakukan pada 10 ibu post partum di wilayah kerja Sidomulyo Rawat Jalan Pekanbaru pada tanggal 22 Desember 2018 didapatkan 6 ibu mengatakan bahwa ia mengalami stres setelah melahirkan dan mengeluh air susu tidak lancar sehingga berdampak terhadap produksi ASI.

\section{METODE}

Jenis penelitian ini merupakan penelitian kuantitatif dengan desain pra eksperimen, menggunakan one group pretest postest dengan uji paired t test. Uji paired $t$ test digunakan pada 1 kelompok yang diukur 2 kali yaitu sebelum dan sesudah perlakuan. Penelitian ini telah dilaksanakan pada tanggal $21 \mathrm{~s} / \mathrm{d} 29$ Maret 2019 di Wilayah Kerja Puskesmas Sidomulyo Rawat Jalan 
Magdalena et al, Pengaruh Pijat Oksitosin Terhadap Produksi ASI Ibu Menyusui di Wilayah Kerja Puskesmas Sidomulyo Rawat Jalan Pekanbaru

Pekanbaru. Populasi dalam penelitian ini adalah seluruh ibu menyusui yang ada di wilayah kerja Puskesmas Sidomulyo Rawat Jalan Pekanbaru. Pengambilan sampel menggunakan dengan purposive sample sebanyak 16 responden, dimana 16 responden diberikan intervensi pijat oksitosin. Teknik pengumpulan data yaitu ada 2 tahap. Tahap pertama, peneliti memilih responden sesuai dengan kriteria inklusi yang telah ditetapkan dan peneliti menjelaskan tentang maksud dan tujuan penelitian dan meminta persetujuan responden dengan cara menandatangani lembar persetujuan menjadi responden dan mengisi data biografi meliputi inisial, usia, alamat, paritas, pekerjaan dan pendidikan terakhir. Tahap kedua, peneliti melakukan observasi pretest terhadap responden ibu menyusui dengan menggunakan lembar observasi yang telah ditentukan. Peneliti melakukan tindakan pijat oksitosin selama 3 hari berturut-turut. Selanjutnya pada hari ke-4 peneliti melakukan observasi posttest pada kelompok yang diberikan intervensi. Hasil observasi dicatat kedalam lembar observasi. Pada penelitian ini analisis univariat digunakan untuk mendapatkan perbedaan tentang pengaruh pijat oksitosin pada ibu menyusui terhadap produksi ASI dengan menggunakan metode statistik. Analisa bivariat yang digunakan pada penelitian ini adalah menggunakan uji statistic TDependent.

\section{HASIL DAN PEMBAHASAN \\ Analisa Univariat}

Produksi ASI Berdasarkan Frekuensi Menyusu Bayi Sebelum Dilakukan Pijat Oksitosin

Tabel 1. Produksi ASI Berdasarkan Frekuensi Menyusu Bayi Sebelum Dilakukan Pijat Oksitosin

\begin{tabular}{cccc}
\hline No & Frekuensi Menyusu Bayi & Orang & $\%$ \\
\hline 1 & Baik & - & - \\
2 & Tidak Baik & 16 & 100 \\
& Jumlah & 16 & 100 \\
\hline
\end{tabular}

Dilihat dari 1, dari 16 responden sebelum dilakukan pijat oksitosin, terdapat 16 responden (100\%) yang frekuensi menyusu bayinya $<8-12$ kali sehari (tidak baik).

Produksi ASI Berdasarkan Frekuensi Buang Air Kecil Bayi Sebelum Dilakukan Pijat Oksitosin
Tabel 2. Produksi ASI Berdasarkan Frekuensi Buang Air Kecil Bayi Sebelum Dilakukan Pijat Oksitosin

\begin{tabular}{cccc}
\hline No & Frekuensi BAK Bayi & Orang & $\%$ \\
\hline 1 & Baik & - & - \\
2 & Tidak Baik & 16 & 100 \\
& Jumlah & 16 & 100 \\
\hline
\end{tabular}

Dilihat dari tabel 2, dari 16 responden sebelum dilakukan pijat oksitosin, terdapat 16 responden (100\%) yang frekuensi buang air kecil bayinya <6-8 kali sehari (tidak baik).

Produksi ASI Berdasarkan Frekuensi Menyusu Bayi Setelah Dilakukan Pijat Oksitosin

Tabel 3. Produksi ASI Berdasarkan Frekuensi Menyusu Bayi Setelah Dilakukan Pijat Oksitosin

\begin{tabular}{cccc}
\hline No & Frekuensi Menyusu Bayi & Orang & $\%$ \\
\hline 1 & Baik & 9 & 56,2 \\
2 & Tidak Baik & 7 & 43,8 \\
& Jumlah & 16 & 100 \\
\hline
\end{tabular}

Dilihat dari tabel 3, dari 16 responden yang telah dilakukan pijat oksitosin, terdapat 9 responden $(56,2 \%)$ yang frekuensi menyusu bayinya $\geq 8$-12 kali sehari (baik) dan 7 responden $(43,8 \%)$ yang frekuensi menyusu bayinya $<8-12$ kali sehari (tidak baik).

\section{Produksi ASI Berdasarkan Frekuensi Buang Air Kecil Bayi Setelah Dilakukan Pijat Oksitosin}

Tabel 4. Produksi ASI Berdasarkan Frekuensi Buang Air Kecil Bayi Setelah Dilakukan Pijat Oksitosin

\begin{tabular}{cccc}
\hline No & Frekuensi BAK Bayi & Orang & $\%$ \\
\hline 1 & Baik & 9 & 56,2 \\
2 & Tidak Baik & 7 & 43,8 \\
\hline & Jumlah & 16 & 100 \\
\hline
\end{tabular}

Dilihat dari tabel 4, dari 16 responden yang telah dilakukan pijat oksitosin, terdapat 9 responden $(56,2 \%)$ yang frekuensi buang air kecil bayinya $\geq 6-8$ kali sehari (baik) dan 7 responden $(43,8 \%)$ yang frekuensi buang air kecil bayinya $<6-8$ kali sehari (tidak baik).

\section{Analisa Bivariat}

Tabel 5. Hasil Uji Statistik Wilcoxon Pengaruh Pijat Oksitosin Terhadap Produksi ASI Ibu Menyusui di Wilayah Kerja Puskesmas Sidomulyo Rawat Jalan Pekanbaru

\begin{tabular}{|c|c|c|c|c|c|c|}
\hline \multicolumn{2}{|c|}{ Variabel } & $\mathbf{N}$ & Mean & SD & $\mathbf{Z}$ & $p$-value \\
\hline Меруия & Pre test & 16 & 5.75 & 1.183 & $3573 a$ & $0 \cap 0$ \\
\hline Menyusu & Post test & 16 & 7.94 & 1.6111 & $-3.5 / 3^{a}$ & .000 \\
\hline $\mathrm{BAK}$ & Pre test & 16 & 4.06 & .772 & $3547^{\mathrm{a}}$ & 000 \\
\hline & Post test & 16 & 6.31 & 1.537 & & \\
\hline
\end{tabular}

Dari tabel 5 dapat dilihat bahwa nilai hasil uji statistik menggunakan uji Wilcoxon menunjukan rata- rata frekuensi menyusu bayi pretest adalah 5.75 kali sehari dan rata-rata frekuensi menyusu bayi posttest 
adalah 7.94 kali sehari. Angka ini menunjukkan peningkatan rata-rata sebesar 2.19 kali sehari setelah dilakukan intervensi pijat oksitosin. Pada rata-rata frekuensi buang air kecil bayi pretest adalah 4.06 kali sehari dan rata-rata frekuensi buang air kecil bayi posttest adalah 6.31 kali sehari. Angka ini menunjukkan peningkatan rata-rata sebesar 2.25 kali sehari setelah dilakukan intervensi pijat oksitosin. Hasil uji statistik Wilcoxon didapatkan nilai $\mathrm{Z}$ frekuensi menyusu bayi sebesar -3.573a dan p-value frekuensi menyusu bayi sebesar 0.000 pada $\alpha 5 \%$ dan nilai $\mathrm{Z}$ frekuensi buang air kecil bayi sebesar -3.547a dan p-value frekuensi buang air kecil bayi sebesar 0.000 pada $\alpha 5 \%$, yang berarti bahwa $p$-value $<\alpha$. Jadi dapat disimpulkan ada pengaruh pijat oksitosin terhadap produksi ASI ibu menyusui di wilayah kerja Puskesmas Sidomulyo Rawat Jalan Pekanbaru.

\section{Pembahasan}

Analisis bivariat yang digunakan dalam penelitian ini adalah menggunakan uji statistic Wilcoxon dikarenakan didapati distribusi data tidak normal. Uji Wilcoxon ini akan menguji pada satu sampel berpasangan (dua pengamatan), yakni ingin membandingkan dua pengamatan yang berasal dari satu sampel. Prinsipnya adalah ingin menguji apakah ada perbedaan dari perlakuan (Hidayat, 2014).

Penelitian ini dilakukan dengan cara memberikan pijat oksitosin selama 10- 15 menit dan selama 3 hari berturut-turut pada ibu menyusui yang memiliki masalah dalam produksi ASI. Secara teori dapat dijelaskan bahwa refleks oksitosin diproduksi oleh bagian belakang hipofisis. Hormon tersebut dihasilkan bila ujung saraf diujung puting dirangsang oleh isapan dan dapat dibantu dengan pijat punggung oksitosin. Oksitosin akan dialirkan melalui darah menuju payudara yang akan merangsang kontraksi otot di sekeliling alveoli sehingga ASI mengalir keluar (Ariani,2009).

Selama penelitian, sebelum dilakukan intervensi pijat oksitosin didapatkan hasil wawancara bahwa responden mengeluh produksi ASI yang sedikit sehingga menghambat pemberian ASI pada bayi, beberapa responden melakukan penanganan dengan cara kompres hangat pada payudara. Setelah dilakukan pijat oksitosin mayoritas responden mengatakan merasa nyaman dan rileks. Hal ini sejalan dengan teori Widuri (2013) yang mengatakan kerja hormon oksitosin sangat dipengaruhi perasaan dan pikiran ibu, agar proses menyusui bisa berjalan dengan lancar, maka ibu harus dalam keadaan tenang, nyaman, dan senang saat menyusui. Namun apabila ibu dalam keadaan stres, maka refleks turunnya air susu ibu dapat terhalangi.

Peneliti berasumsi bahwa pijat oksitosin yang diberikan pada responden yang memiliki masalah produksi ASI dapat melancarkan produksi ASI, hal ini dikarenakan dapat memberikan kenyamanan pada ibu. Kenyamanan yang dirasakan oleh ibu akan dapat dirasakan oleh bayi, sehingga bayipun merasa nyaman dan dapat menyusu dengan lebih baik. Pelaksanaan pijat oksitosin dilakukan peneliti sesuai dengan teori dan SPO yang ada, yaitu dengan cara responden duduk bersandar kedepan, melipat lengan di atas meja didepannya, dan meletakkan kepala diatas lengannya. Payudara tergantung lepas, tanpa pakaian. Peneliti berdiri memijat dari belakang, kepalan tangan ditempatkan di kedua sisi dari tulang punggung diketinggian yang sama dengan payudara dan menggosokkan kepalan tangan bergerak ke bawah hingga setinggi tulang belikat.

Teori yang mendukung asumsi peneliti yaitu menurut Widuri (2013) yang menyatakan bahwa hormon oksitosin juga disebut "hormon kasih sayang" karena hampir $80 \%$ hormon ini dipengaruhi oleh pikiran ibu (positif atau negatif). Pikiran positif ibu akan memperlancar pengeluaran hormon ini, demikian sebaliknya. Suherni, Widyasih, H \& Rahmawati, A, (2009) mengatakan bahwa pijat oksitosin merupakan suatu tindakan atau metode pemijatan tulang belakang mulai dari inter costa ke 5-6 sampai skapula akan mempercepat kerja saraf parasimpatis untuk menyampaikan perintah ke otak bagian belakang sehingga oksitosin keluar yang merupakan hormon yang dapat membantu pengeluaran air susu dari alveoli ke sistem duktus laktiferus melalui kontraksi sel mioepitelium, mengurangi stres pada ibu nifas, meningkatkan kenyamanan dan relaksasi tubuh.

Hasil penelitian yang dilakukan oleh peneliti, dari 16 responden terdapat 9 responden yang produksi ASI nya lancar setelah dilakukan pijat oksitosin sedangkan 7 responden produksi ASI nya tidak lancar. Setelah dilakukan wawancara terhadap 9 responden yang mengalami kelancaran produksi ASI, responden mengatakan adanya dukungan keluarga terutama suami yang ikut membantu pelaksanaan pijat oksitosin terhadap responden dirumah. Berdasarkan hasil penelitian menggunakan uji statistik Wilcoxon didapatkan nilai p-value frekuensi menyusu sebesar 0.000 pada $\alpha 5 \%$ dan didapatkan p-value frekuensi buang air kecil sebesar 0.000 pada $\alpha 5 \%$, yang berarti bahwa p-value $<\alpha$. Jadi dapat disimpulkan ada pengaruh pijat oksitosin terhadap produksi ASI ibu menyusui di wilayah kerja Puskesmas Sidomulyo Rawat Jalan Pekanbaru.

Penelitian yang mendukung adalah penelitian dilakukan oleh Putri (2017) tentang Pengaruh Pijat Oksitosin terhadap Produksi ASI Ibu Post Partum, pada 30 responden yang dibagi dalam 2 kelompok yakni, 15 responden yang diberikan intervensi pijat oksitosin didapatkan hasil 86,7\% terjadi kecukupan produksi ASI dan $13,3 \%$ yang tidak cukup produksi ASI. Namun, pada 15 responden yang tidak diberikan intervensi didapatkan hasil 46,7\% terjadi kecukupan produksi ASI dan 53,3\% yang tidak cukup produksi ASI. Setelah dilakukan uji statistik Chi-Square pada responden kelompok intervensi dan control diperoleh nilai $p$-value sebesar 0,020 
$(\mathrm{p}<0,05)$ yang berarti bahwa ada pengaruh yang signifikan dari pijat oksitosin terhadap produksi ASI pada ibu post partum di Puskesmas Sei Langka tahun 2017.

Penelitian diatas sejalan dengan pendapat Mardiyaningsih (2010) bahwa produksi ASI sangat dipengaruhi oleh hormon prolaktin yang akan memproduksi ASI, dan hormon oksitosin yang berpengaruh pada kelancaran pengeluaran ASI, karena semakin ASI keluar produksi ASI akan semakin meningkat. Jadi dapat disimpulkan bahwa pijat oksitosin merupakan salah satu solusi untuk mengatasi ketidaklancaran produksi ASI dengan merangsang hormon oksitosin pada ibu post partum dengan tujuan merelaksasikan ibu yang menyusui, pijat ini aman dan mudah dilakukan baik oleh tenaga medis maupun anggota keluarga.

\section{SIMPULAN}

Berdasarkan hasil analisis rata-rata frekuensi menyusu bayi sebelum dilakukan pijat oksitosin adalah 16 responden $(100 \%)<8-12$ kali sehari dan rata-rata frekuensi buang kecil bayi sebelum dilakukan pijat oksitosin adalah 16 responden $(100 \%)<6-8$ kali sehari dan rata-rata frekuensi menyusu bayi setelah dilakukan pijat oksitosin adalah terdapat 9 responden $(56,2 \%)$ yang frekuensi menyusu bayinya $\geq 8-12$ kali sehari dan 7 responden $(43,8 \%)$ yang frekuensi menyusu bayinya $<8$ 12 kali sehari sedangkan rata-rata frekuensi buang air kecil bayi setelah dilakukan pijat oksitosin adalah terdapat 9 responden $(56,2 \%)$ yang frekuensi buang air kecil bayinya $\geq 6-8$ kali sehari dan 7 responden $(43,8 \%)$ yang frekuensi buang air kecil bayinya $<6-8$ kali sehari. Pada hasil uji statistik Wilcoxon didapatkan nilai $p$-value frekuensi menyusu bayi sebesar 0.000 pada $\alpha 5 \%$ dan didapatkan $p$-value frekuensi buang air kecil bayi sebesar 0.000 pada $\alpha 5 \%$, yang berarti bahwa $p$-value $<\alpha$. Jadi dapat disimpulkan ada pengaruh pijat oksitosin terhadap produksi ASI ibu menyusui di wilayah kerja Puskesmas Sidomulyo Rawat Jalan Pekanbaru.

\section{DAFTAR PUSTAKA}

Ariani. (2009). Ibu, Susui Aku. Bandung : Khazanah Intelektual.

Astutik, R. Y. (2015). Asuhan kebidanan masa nifas dan menyusui. Jakarta : TIM.

Bobak, I. M, Lowdermilk, D. L \& Jensen, M. D. (2012). Buku Ajar Keperawatan Maternitas. Jakarta : EGC.

Dinas Kesehatan Provinsi Riau. Profil Kesehatan Provinsi Riau 2016. Pekanbaru: Dinas Kesehatan Provinsi Riau : 2016.

Donsu, J. D. T. D. (2016). Metodologi Penelitian Keperawatan. Yogyakarta : Pustaka baru Press.

Hidayat, A. Azizul Alimul. (2010). Metode Penelitian Kebidanan dan Teknik Analisis Data. Jakarta : Salemba Medika
Janiwarty, B., \& Pieter, H. Z. (2013). Pendidikan Psikologi untuk Bidan, Suatu Teori dan Penerapannya. Yogyakarta : Rapha Publishing.

Kemenkes RI. (2018). Riset Kesehatan Dasar 2018. Indonesia : Jakarta.

Manuaba,I.B.G., Chandra, M.I.A., Fajar, M.I.B.G. (2010) Pengantar Kuliah Obstretri. Jakarta : EGC

Maryunani, Anik. (2009). Asuhan pada Ibu Dalam Masa Nifas. Jakarta : CV. Trans Info Media

Notoatmodjo. S. (2012). Metodologi Penelitian Kesehatan. Jakarta : Rineka Cipta

Nursalam, Pariani. (2011). Konsep dan Penerapan Metodologi Penelitian Ilmu Keperawatan Edisi 2. Jakarta : Salemba Medika.

Pusat Data dan Informasi Kementerian Kesehatan RI. (2014). Situasi dan Analisis ASI Ekslusif. Indonesia : Jakarta

Putri, Y. D. (2017) Pengaruh Pijat Oksitosin Terhadap Produksi ASI Ibu Post Partum Kota Batam. Jurnal Kesehatan STIKes Mitra Bunda Persada Vol. 10 No 1 Januari 2018.

Roesli, Utami. (2012). Panduan Konseling Menyusui. Jakarta : Pustaka Bunda.

Saleha, S. (2009). Asuhan Kebidanan pada Masa Nifas. Jakarta : Salemba Medika.

Setiadi. (2013). Konsep dan Penulisan Riset Keperawatan. Yogyakarta : Graha Ilmu

Sugiyono, Prof, Dr. (2011). Metode Penelitian Kuantitatif, Kualitatif, dan R \& D. Bandung : CV Alfabeta

Suherni, Widyasih, H \& Rahmawati, A. (2009). Perawatan masa nifas. Yogyakarta : Fitramaya.

Walyani, Elisabeth siwi. (2015). Perawatan Kehamilan dan Menyusui Anak Pertama Agar Bayi Lahir Dan Tumbuh Sehat. Yogyakarta : Pustaka baru Press.

WHO. (2016). Infant and Young Child Feeding. English. Diperoleh tanggal 22 Desember 2018.

Widuri, Hesti. (2013). Cara Mengelola Asi Ekslusif Bagi Ibu Bekerja. Yogyakarta: Gosyen Publishing.

Yanti, D., \& Sundawati, D. (2011) Asuhan Kebidanan Masa Nifas. Bandung : PT Refika Aditama. 